\title{
POETYCKA HISTORIA I KRYTYKA LITERATURY W UJĘCIU CZESŁAWA MILOSZA
}

\author{
Kamil DŹWINEL (Toruń)
}

Utwory literackie są przedmiotem namysłu nie tylko krytyków, badaczy literatury i „zwykłych” czytelników, lecz także poetów, uprawiających szczególny rodzaj liryki, który można by nazwać ,poezją literaturoznawczą".

Ten wariant refleksji nad literaturą wyłamuje się, rzecz jasna, spod ścisłych rygorów dyskursu naukowego, niemniej w niektórych ujęciach zyskuje walor poznawczy bliski typowemu literaturoznawstwu. Nie można jednak zapominać, że prymarną funkcją takiego komunikatu pozostaje niezbywalnie funkcja estetyczna, poetycka. Ujęcie danego problemu literackiego, szkoły pisarskiej czy stylu pojedynczego autora bądź dzieła w obrębie wiersza cechuje zawsze określenie się podmiotu lirycznego wobec wybranych elementów omawianego zagadnienia: języka poetyckiego, treściowych uwarunkowań, genezy utworu, tradycji literackiej itp. Immanentnym elementem opisywanego zjawiska artystycznego (które, prócz swych artystycznych, nadrzędnych funkcji, posiada również epistemiczną perspektywę naukowości) jest więc także intencja polemiczna lub - jeśli nie dochodzi do podważenia wymienionych powyżej zagadnień literackich — przynajmniej syntetyzująca, akcentująca pożądaną cechę.

„Poezję literaturoznawczą” postrzegać należy nie jako gatunek, jest ona raczej swoistym fenomenem, który sytuuje się na pograniczu podmiotowości i intersubiektywności, nauki i wolnomyślicielstwa, filozofii sztuki i teorii poznania, a wreszcie nauki o literaturze i poetyckiej praxis. Twórczość tego typu może być doskonałym probierzem zainteresowań literackich kolejnych pokoleń pisarzy, pokazuje bowiem, na jakie tendencje poszczególni autorzy zwracali uwagę, co podlegało artystycznej akceptacji, a co spotykało się z polemiką i odrzuceniem. „Literaturoznawcza” liryka jest specyficzną odmianą poezji autotematycznej. Metapoetyckie komunikaty są relewantnymi elementami tego typu twórczości. Poetycka refleksja podjęta nad danym, interesującym autora zagadnieniem „okołoliterackim”, choćby rozważania nad twórczością 
określonej grupy poetyckiej ${ }^{1}$, prowadzi w niemal każdym wypadku do sądów ogólnych, dotyczących istoty literatury, procesu twórczego, funkcji dzieła, sposobu formalnego konstruowania utworu, zagadnień związanych z językiem, problematyką słowa, natchnienia czy powinności poety wobec rzeczywistości i własnej ars poetica. Powyższy katalog to oczywiście typowe wątki autotematyczne, kierunkujące podmiotową refleksję autora na własne dzieło i — ogólnie biorąc — proces jego powstawania, co prowadzi z kolei do podjęcia przez odbiorcę obserwacji warsztatu pisarskiego, sposobu uprawiania poetyckiej sztuki. „Poezja literaturoznawcza” jest więc, powtórzmy, z gruntu autotematyczna, co czyni ją w pewnej mierze odpowiednikiem typowego raczej dla prozy modelu „powieści jako metodologii powieści”2.

$\mathrm{Z}$ omawianym tu zjawiskiem literackim nierozerwalnie łączy się stylizacja, występująca najczęściej w odmianie pastiszu. Nie mamy tu do czynienia z próbą uzyskania żartobliwego efektu, ale raczej z formą „krytycznoliterackiej penetracji cudzego stylu"”. Bliżej więc tej cesze pastiszu do Pięciu pocztówek od i do Emily Dickinson Stanisława Barańczaka, gdzie autor Atlantydy podejmuje polemikę z "afirmacją pomimo" dokonaną przez poetkę, budując wiersz całkowicie w jej stylu (zarówno pod względem formalnym - pełna imitacja, jak i znaczeniowym - polemika z zaproponowanym przez poetkę widzeniem świata), aniżeli do cyklu Kazimierza Wyki Duchy poetów podstuchane, z pobrzmiewającą $\mathrm{w}$ nim nutą parodystyczną. Domeną takiej czynności twórczej jest uchwycenie w pisarskiej praktyce tych cech stylu danego dzieła lub autora, które są teoretycznie eksplikowane właśnie przez badaczy literatury. Pastisz zawiera jasną intencję polemiczną, choć równie często jest wyrazem podziwu wyrażonego przez autora pod adresem innego pisarza czy utworu.

Powyższe uwagi - zastrzeżmy raz jeszcze - nie wiążą się z postulowaniem nowego gatunku. Koncepcja „poezji literaturoznawczej” wzięła się raczej z uświadomienia sobie powtarzalności tego typu wierszy w dorobku poszczególnych pisarzy, przy jednoczesnym występowaniu sumy charakterystycznych cech. Wyróżniona tendencja literacka dobitnie wskazuje także na proces migracji różnych poetyk w obrębie piśmienniczego uniwersum. Daje również wyraz „dialogiczności” literatury, intertekstualności, która - w najszerszym znaczeniu — wiąże się z nieustanną interferencją tekstów w obrębie innych tekstów.

Jedne z najciekawszych przykładów poezji o literaturze możemy odnaleźć w twórczości Czesława Miłosza. Poeta ten jest ważnym reprezentantem omawianej tendencji, być może dlatego, że — oprócz intensywnej praktyki pisarskiej — pełnił w ciągu swe-

\footnotetext{
${ }^{1}$ Doskonałym przykładem polemicznych rozważań nad twórczością Pokolenia '68 jest wiersz Zbigniewa Herberta Do Ryszarda Krynickiego — list, w którym autor Rovigo stawia pytania o naturę (także formalną) poezji, nie godząc się na sprowadzanie jej języka „do bełkotu z trybuny do czarnej piany gazet"; Z. Herbert, Wiersze zebrane, ed. R. Krynicki, Kraków 2008, s. 464. Poetycko uogólnia Pokolenie ' 68 - reprezentantem głównym czyniąc właśnie autora Aktu urodzenia - by, polemizując z jego propozycjami poetyckimi, zbudować liryczną wypowiedź autotematyczną.

${ }^{2}$ Określenie Michała Głowińskiego, które posłużyło mu za tytuł jednego z najważniejszych tekstów dotyczących zagadnień autotematyzmu w prozie. Proponowany model „poezji literaturoznawczej" mógłby stanowić odpowiednik propozycji badacza na terenie refleksji lirycznej; zob.: M. Głowiński, Powieść jako metodologia powieści, [w:] tegoż, Porzadek, chaos, znaczenie. Szkice o powieści wspótczesnej, Warszawa 1968.

${ }^{3}$ J. Sławiński, Pastisz, [hasło w:] Stownik terminów literackich, red. tegoż, Wrocław 1976, s. 296.

${ }^{4}$ Zob.: K. Biedrzycki, Wzruszenie ramionami. O historii w literaturze polskiej lat dziewięćdziesiatych, [w:] tegoż, Wariacje metafizyczne. Szkice i recenzje o poezji, prozie i filmie, Kraków 2007, s. 393-394.
} 
go życia również funkcję wykładowcy literatury słowiańskiej na kalifornijskim uniwersytecie w Berkeley. Jego literaturoznawcze kompetencje potwierdza także obszerna Historia literatury polskiej, skierowana pierwotnie do amerykańskich studentów. Co jednak najistotniejsze - Miłosz nigdy nie zatracił pasji i głębokiego umiłowania dla literatury narodowej, nie kryjąc satysfakcji eksploratora polskiego dziedzictwa piśmienniczego: „Pracując, ani przez chwilę nie odczuwałem nudy; w istocie raczej bawiłem się, niż mozoliłem, i mam nadzieję, że niektóre ustępy zachowały ślad mojego śmiechu"s. Zaznacza także, iż zależało mu na uniknięciu „uczonej suchości”6 — od której ucieka zresztą i wtedy, kiedy przyjmuje formę poezji „literaturoznawczej”. Miłoszowskie pasje w odkrywaniu szerokich horyzontów literatury, w przybliżaniu jej tajemnic, a także pokazy kunsztownej sztuki interpretacji można bez trudu znaleźć w jego eseistyce oraz felietonistyce ${ }^{7}$.

Nieprzebranym źródłem lirycznych rozważań o literaturze jest oczywiście Traktat poetycki. Jan Błoński zauważa, że sytuacja komunikacyjna poematu przypomina wykład, chodzi przy tym nie o wykład w tradycyjnym tego słowa znaczeniu, istotne są cechy, strategia mówiącego:

Miłosz rozpracowuje szanse płynące $\mathrm{z}$ miarkowanej zażyłości mówiącej jednostki z niewielką (i wtajemniczoną!) społecznością. Jest za bardzo nauczycielem, aby pozwolić sobie na gawędziarstwo. Ale za bardzo poetą, aby czytelnikowi przyłoić godzinnym przemówieniem $^{8}$.

Badacz stwierdza także, że „Traktat jest dziełem mędrca, który wie”", czym podkreśla przenikliwość poczynionej w tym utworze refleksji, jej doniosłość poznawczą, zwraca także uwagę na (połączoną z „wtajemniczeniem” z poprzedniego cytatu) ,iluminację" świadomości podmiotu. Oto otrzymujemy bowiem zarys dziejów poezji polskiej XX w., z szerokim kontekstem historycznym i historiozoficznym. Odnaleźć można w tym utworze pokaźną galerię polskich poetów wraz z krótkimi charakterystykami ich twórczości, biografii i miejsca na mapie literatury. Miłosz nie ucieka się tu do pastiszowego potraktowania poszczególnych twórców, ale w logicznym, precyzyjnym wywodzie kreśli sylwetki i poetyki. Czynność ta stanowi przecież główne zaplecze metodologiczne literaturoznawców. Poeta staje się w tej chwili badaczem twórczości innych pisarzy, nie stroni rzecz jasna od ostrych ocen (np. politycznej postawy Juliana Tuwima), ale próbuje jednak ukazać poszczególne „biografie twórcze” na planie ogólnym, zsyntetyzować najważniejsze cechy, zawrzeć w tych kilku (czasem tylko dwóch) wersach poematu możliwie trafny sąd o danym artyście czy tendencji literackiej. Jeden z badaczy stwierdza wręcz, że „w konstrukcji Miłoszowskiego komunikatu poetyckiego dokonuje się nawrót do logiczno-retorycznej budowy zdania, zdolnego unieść treści intelektualnego dyskursu, odtworzyć proces myślenia pojęciowego" ${ }^{\text {10 }}$. Autor Ziemi Ulro dokonuje

${ }^{5}$ Cz. Miłosz, Historia literatury polskiej, przeł. M. Tarnowska, Kraków 2010, s. 11.

6 Tamże.

${ }^{7}$ Przywołajmy choćby zbiór Spiżarnia literacka (Kraków 2004, wyd. 2: Kraków 2011), w którym zebrano jego felietony związane z literaturą ogłaszane na łamach „Tygodnika Powszechnego". Warto pamiętać także o Życiu na wyspach (Kraków 1997) oraz o szkicach na temat twórczości takich poetów jak Stanisław Barańczak, Wisława Szymborska czy Julia Hartwig - pomieszczonych w zbiorze O podróżach w czasie (Kraków 2004, wyd. 2: Kraków 2010).

${ }^{8}$ J. Błoński, Powrót intelektu: „Traktat poetycki” (1957), [w:] tegoż, Miłosz jak świat, Kraków 1998, s. 40.

${ }^{9}$ Tamże, s. 37

${ }^{10}$ M. Zaleski, O poezji „,traktatowej”, Pamiętnik Literacki 1977 z. 3, s. 168. 
w swoim Traktacie poetyckim — powiedzieć należy wprost - historycznoliterackiej syntezy. Jego sądy, wyrażone w dostojnej, zintelektualizowanej frazie, próbują powiązać ze sobą poszczególne zjawiska literackie, dociec kształtu historycznoliterackiego procesu, a przede wszystkim - dokonać prezentacji najbardziej wymownych dla epoki twórców. Miłosz nie szczędzi przy tym także tonów polemicznych, co tylko dowodzi krytycznej funkcji Traktatu ${ }^{11}$. Błoński nazywa ten utwór również „grą konwencji” i ,grą tekstów”, ${ }^{2}$, zwracając uwagę także na liczne przytoczenia w obrębie poematu (choćby fragmentów quasi-kolęd z Pastorałek Tytusa Czyżewskiego, cytatów z Mickiewicza czy z Pieśni Horacego). Traktatowa liryka Miłosza stanowi bez wątpienia przykład „,poezji literaturoznawczej”, na podstawie której można z powodzeniem odtworzyć główne nurty młodopolskiej, międzywojennej oraz wojennej poezji polskiej. Poeta-,,badacz" nie szczędzi także miejsca na wyraziste zarysowanie tła historyczno-politycznego, zanim przechodzi do wątków związanych z dziejami i kształtem poezji:
A jednak jesteś. $Z$ czarnym twoim gettem,
$\mathrm{Z}$ bezrobotnymi, których gniew jest senny,
Ze łzami kobiet w przedwojennej chustce.
Latami będzie chodzić w Belwederze.
Piłsudski nigdy nie uwierzy w trwałość.
I będzie mruczeć: „Oni nas napadną"13.

W powyższym fragmencie przywołane zostaje getto warszawskie, a także postać Józefa Piłsudskiego, bez którego fenomenu nie sposób zrozumieć niektórych poetyckich zjawisk (przypomnieć należy chociażby tom Kazimierza Wierzyńskiego Wolność tragiczna, którego bohaterem jest właśnie marszałek Piłsudski oraz estymę, jaką darzył naczelnika państwa Jan Lechoń). Takie historyczne tło to bardzo istotny element dyskursu literaturoznawczego. $Z$ równą wprawą, co także widać w przytoczonej strofie, odtwarza Miłosz także koloryt epoki. Getto jest „,czarne”, ponieważ zamieszkiwali je Żydzi noszący ubrania o takim właśnie kolorze ${ }^{14}$, panuje bezrobocie i bezsilność. Poeta zarysowuje bardzo wyraźnie, z użyciem licznych nazw gwarowych (ober, szyfkarta, tingel-tangel) oraz elementów charakterystycznych dla epoki (gazety na kiju, filmy w ,iluzyonie", fiakrzy spod Mariackiej Wieży) ${ }^{15}$, wizję Polski z pierwszych dekad XX w. Jego poetycka panorama dziejów poprzedzona jest spoistym, treściwym obrazem omawianych epok (widać to szczególnie w Pięknych czasach oraz Stolicy), przywołanym nie tyle jako resentyment, ale jako tło właśnie, jako niezbywalny klimat i charakter opisywanych czasów, jako podstawa „badawcza”. W jednym z wywiadów autor Dla Heraklita tak charakteryzuje tło historyczne odwzorowane w Traktacie...:

W całym Traktacie poetyckim jest przecież bardzo dużo historii. A co to jest historia? To są ludzie - ci, którzy żyli i już nie żyją. Nie jakaś historia abstrakcyjna, tylko ta, którą się odsłania w obrzędzie Dziadów, przywoływania dusz ${ }^{16}$.

\footnotetext{
${ }^{11}$ Zob.: tamże, s. 169-172.

12 J. Błoński, Powrót intelektu, s. 41-42.

${ }^{13}$ Cz. Miłosz, Traktat poetycki z moim komentarzem, Kraków 2001, s. 31-32.

${ }^{14}$ Zob. komentarz Miłosza: tamże, s. 31.

15 Przykłady nazw gwarowych oraz elementów charakterystycznych dla epoki pochodzą z części pierwszej Traktatu poetyckiego pt. Piękne czasy.

${ }^{16}$ Cz. Miłosz, Traktat poetycki, Traktat moralny. Lekcja literatury z Czestawem Miłoszem, Aleksandrem Fiutem i Andrzejem Franaszkiem, Kraków 1996, s. 10-11.
} 
Właśnie z poglądu, że historię tworzą losy jednostek, wzięła się pieczołowitość w odtwarzaniu elementów przeszłej rzeczywistości.

Przyjrzyjmy się kilku fragmentom Traktatu poetyckiego, by uzmysłowić sobie sposób budowania przez Miłosza ,poezji literaturoznawczej” oraz wprowadzania w obręb refleksji artystycznej sądów syntetyzujących. Tak oto scharakteryzowana zostaje sylwetka Jana Lechonia:

$$
\begin{aligned}
& \text { Wiosnę, nie Polskę, chciał widzieć na wiosnę } \\
& \text { Depczący przeszłość Lechon-Herostrates. } \\
& \text { Ale rozmyślać miał przez całe życie } \\
& \text { O słuckich pasach i o karmazynie } \\
& \text { Czy o religii, choć nie katolickiej, } \\
& \text { A tylko polskiej, na mszy narodowej } \\
& \text { Kapłanem w komży mianując Or-Ota }{ }^{17} \text {. }
\end{aligned}
$$

Miłosz bardzo przenikliwie skonstatował dominantę twórczości autora Srebrnego i czarnego, czyli ogólnie pojętą polskość (może nawet „chorobę” na polskość). Po pierwszym tomie, w którym wyłożona zostaje Lechoniowa „religia polskości”, obwarowana tradycyjnym wierszem oraz sarmacko-romantyczną rekwizytornią schematów (twórczo zinterpretowaną), poeta staje się bezsilny wobec emigracyjnej sytuacji, w jakiej się znalazł. Dlatego właśnie rozmyślać ma ,przez całe życie” o tych fantazmatach polskości, niemalże ignorując amerykańską rzeczywistość, w której przyszło mu egzystować, a także bezpardonowo oscylując wokół katalogu tych samych, patriotycznych motywów (znamienny zdaje się tu wiersz Naśladowanie Or-Ota; postać Artura Oppmana, którego Lechoń wielce cenił za jego poezję o Warszawie, wydaje się nieprzypadkowo przywołana przez autora Kontynentów jako „domknięcie”, swoiste „błędne koło”). Nie bez powodu Lechoń zostaje utożsamiony z bohaterem jednego ze swych najgłośniejszych wierszy - Herostratesem: ,[...] jednakże jeden z wierszy koliduje $\mathrm{z}$ innymi $\mathrm{w}$ tym tomie [Karmazynowym poemacie - K. D.], który tak na serio zajmuje się sprawami publicznymi: Herostrates wysławia bunt przeciwko wszelkim formom zaangażowania"18 — w skrótowym oglądzie poezji autora Balu u senatora zamieszczonym w Historii literatury polskiej również ten wiersz przywołuje Miłosz jako reprezentatywny dla właściwego debiutu młodego poety ${ }^{19}$. Strofa o Lechoniu jest niezmiernie syntetyczna, cechuje ją (jak zresztą i inne strofy o pisarzach z Traktatu poetyckiego) jednak celność literaturoznawczego oglądu. Synteza w wydaniu Miłosza jest, mimo swej skrótowości, trafna, wskazuje na najistotniejsze czynniki kształtujące poetykę autora Lutni po bekwarku, daje przenikliwy wgląd w osobowość twórczą tego, tylko na pozór prostego w odbiorze, pisarza. Sam Miłosz stwierdza zresztą, że nie należy traktować Lechonia jedynie jako poetę błądzącego wokół własnego debiutu, „można pisać wiersze «zaściankowe» i głęboko poetyckie zarazem” ${ }^{20}$. Sąd ten został wygłoszony co prawda w latach 90., pokazuje jednak, że dość ogólne rozważania z Traktatu poetyckiego Miłosz sumiennie starał się dookreślać, na co nie mógł jednak

${ }^{17}$ Cz. Miłosz, Traktat poetycki z moim komentarzem, s. 35-36.

${ }^{18}$ Tenże, Historia literatury polskiej, s. 457-458.

${ }^{19}$ Jako kontekst dla tej wypowiedzi przywołajmy fragment felietonu Miłosza na temat Lechonia pt. Oczyszczenie: „A jednak biograf będzie musiał skłonić się przed Lechoniem poetą. Wszelkie jego snobizmy, wszelkie jego prowincjonalizmy bledną wobec jednego wiersza, który jest jak spowiedź i oczyszczenie [mowa o wierszu Powstatem nagi z mego snu - K. D.]"; Cz. Miłosz, Spiżarnia literacka, Kraków 2004, s. 100.

${ }^{20}$ Cz. Miłosz, Traktat poetycki, Traktat moralny. Lekcja literatury, s. 22. 
pozwolić sobie w traktatowej, intelektualnie zwięzłej formie. Wskażmy, że taką skłonnością do uproszczeń i może nawet zbyt daleko idących uogólnień cechują się historycznoliterackie syntezy. W rozmowie z Renatą Gorczyńską stwierdza zresztą Miłosz, że jego Traktat jest „,z założenia suchy”, dodając, iż stanowi po prostu „rozumowanie czysto logiczne, bo żyjemy w nadmiarze poezji emocjonalnej, wilgotnej"”21.

Skrótowy, a przez to niekiedy upraszczający, ogląd poszczególnych zjawisk poetyckich jest wynikiem przyjętej formy poematu, który pomieścić ma tak wiele idiolektów, nazwisk i problemów. Wiele z sądów o swych poprzednikach (pozostaje wszak podmiot Traktatu poetą namyślającym się nad własnym rzemiosłem i jego tradycją) znajduje, jak we wspomnianym przypadku Lechonia, późniejsze eseistyczne lub historycznoliterackie rozwinięcia. W obrębie tego utworu mieszczą się jednak tendencje bardzo ważne dla rozwoju polskiej poezji, reprezentowane także przez autorów spoza głównej plejady:
Tam Wittlin ciągle wkłada łyżkę zupy
$\mathrm{W}$ zarosłe usta człowieczego głodu,
Baliński słyszy dzwoneczki karawan
W różowo-szare zmierzchy Ispahanu,
Tytus Czyżewski powtarza zaklęcie
Pasterzy dmących w dudki Jezusowi,
Ważyk ogląda okręt na wystawie,
Iskrzy się fala u Apollinaire'a ${ }^{22}$.

Poetyka skrótu pozwala Miłoszowi na uchwycenie najważniejszych cech, lejtmotywów charakterystycznych dla twórczości danego pisarza. Aby osiągnąć tego typu „ekstrakt” (a nawet, by posłużyć się określeniem Miłosza, „ersatz”), sięga poeta po sztandarowe tytuły z dorobku przywoływanych artystów: Hymn o tyżce zupy Józefa Wittlina, będący wyrazem głębokiego, filozoficznego humanizmu czy Pastoratki Czyżewskiego, przywracające pierwotne, ludowe spojrzenie na świat i Boga. Osiąga dzięki takiemu zabiegowi intelektualną ścisłość. Wymaga też od swego odbiorcy erudycji i szerokiej wiedzy kulturowej, każąc wypełniać „eliptyczność” swego dzieła ${ }^{23}$, miejsca będące „ofiarą" syntetyzowania właśnie. Traktat poetycki postuluje bowiem idealnego czytelnika, jest rozprawą o dziejach i istocie poezji, którą niepodobna pojąć bez wcześniejszego przygotowania, „osłuchania” w twórczości poszczególnych bohaterów poematu. Historia literatury według Miłosza nie spełnia więc w tym wypadku kryterium przystępności (stąd m.in. obszerny odautorski komentarz do Traktatu...), choć niezaprzeczalnie dowodzi jednego faktu: poeta jest wnikliwym kontemplatorem literackiej tradycji, jej wytrawnym znawcą i próbuje swoje sądy przekazać w formie „bardziej pojemnej”, aniżeli typowa historycznoliteracka rozprawa - także z tego powodu wybiera wzorzec traktatu i cierpliwie wypracowuje każdy jego wers. Istnieje w Traktacie poetyckim bardzo silna tendencja do historycznoliterackich uogólnień, co szkicowo zostało tu ukazane, oraz ambicja zaprezentowania dziejów dwudziestowiecznej poezji polskiej, ,a raczej refleksja nad jej miejscem wśród wydarzeń historycznych tego stulecia"24.

Włodzimierz Maciąg tak określa literaturoznawcze diagnozy autora Drugiej przestrzeni poczynione w Traktacie poetyckim:

[...] poezja polska pierwszej połowy stulecia rozpoznana zostaje jako byt duchowy nie-

\footnotetext{
${ }^{21}$ R. Gorczyńska, Cz. Miłosz, Podróżny świata. Rozmowy, Kraków 2002, s. 136.

${ }^{22}$ Cz. Miłosz, Traktat poetycki z moim komentarzem, s. 47.

${ }^{23}$ Por.: J. Błoński, Powrót intelektu, s. 48-49.

${ }^{24}$ Cz. Miłosz, Traktat poetycki z moim komentarzem, s. 5.
} 
zdolny do wyjścia z osaczenia [...], jako idea [...] jakby spętana własnymi iluzjami, ale także surowością czy nawet szczególnym okrucieństwem faktów historycznych ${ }^{25}$.

Ujęcie Miłosza nie tylko więc przedstawia historię poezji polskiej, ale także dokonuje jej rekonesansu ideowego, aksjologicznego. Poeta nie stroni przy tym od próby wskazania źródeł odpowiadających za pewne niedostatki tej poezji (skamandrytom np. wytknie ,skazę harmonii" ${ }^{26}$; nie zapomni także o przemożnym wpływie wojen na biografie twórcze). Takim sumarycznym oglądem głównych tendencji pisarstwa narodowego jest także wiersz Literatura polska, w którym pada surowa diagnoza: „Z uporem dąży do siebie, tej, którą ciągle nie jest" ${ }^{27}$. Z kolei w wierszu Młodzi polscy poeci (z adnotacją Po przeczytaniu „Almanachu młodych 1958-59”) Miłosz dokonuje rekonesansowego rozeznania krytycznoliterackiego w najnowszej twórczości, nie szczędząc sarkazmu: „W nadmorskich wiatrach słyszę wasz jeleni śmiech” ${ }^{28}$. „Poezja literaturoznawcza” nie jest więc domeną Traktatu poetyckiego i - co warto nadmienić ponownie - pełni, poza prymarną funkcją estetyczną, także funkcję poznawczą (z perspektywy podmiotowej zaś — badawczą).

W twórczości Miłosza można odnaleźć znacznie więcej przykładów na dyskurs literaturoznawczy, skupimy się tym razem na wierszach z wyraźną funkcją polemiczną. Teresa Skubalanka analizując poetycki program Miłosza, stwierdza, że ,autor Traktatu poetyckiego często odnosi się krytycznie do tradycyjnej poezji niektórych poprzedników i współczesnych" 29 . Intencja polemiczna wpisana w co poniektóre wiersze zbliża poezję tego typu do krytyki literackiej. Następuje w tych utworach jednak znamienne przesunięcie środka aksjologicznej ciężkości - krytyka, np. czyjegoś programu poetyckiego czy konkretnych rozwiązań formalnych, ma za zadanie wysunięcie własnych poetyckich propozycji na plan pierwszy. Poezja Miłosza — w swych jednostkowych realizacjach - stanowi więc artystyczne odbicie czynności krytycznoliterackich. Znamiennym przykładem polemiki poetyckiej jest wiersz Do Robinsona Jeffersa. Autor Widzeń nad zatoką San Francisco nie godzi się na mroczne, przytłaczające swą apokaliptycznością wizje amerykańskiego poety:

Wąskousty, niebieskooki, bez łaski i nadziei,
przed Bogiem Terribilis, ciałem świata.
Nie wysłuchuje modlitw nikt. Bazalt i granit,
nad nim drapieżny ptak. Jedyne piękno ${ }^{30}$.

Powyższy fragment jest rekonstrukcją artystycznego sposobu myślenia charakterystycznego dla Jeffersa. Miłosz wskazuje na te cechy jego poezji, którym pragnie się przeciwstawić, których jako artysta nie może zaakceptować. Wizja „Boga Terribilis” — strasznego, karzącego — nie mieści się w światopoglądzie „słowiańskiego” poety. Dodaje Miłosz z ironią: „O, te pociechy śmiertelnych, wierzenia daremne!”31 — a odbiorca wie doskonale, że pastisz stylu autora Dear Judas, oparty w gruncie rzeczy na obserwacji poetyki swego ,przeciwnika”, na dokonaniu jej krytycznego (a więc i literaturoznawczego) oglądu, posłużył polskiemu poecie do obrony „odrębności wła-

${ }^{25}$ W. Maciąg, Niezgtębiona wielorakość istnienia. „Traktat poetycki” Czesława Miłosza, [w:] tegoż, Nasz wiek XX. Przewodnie idee literatury polskiej 1918-1980, Wrocław 1992, s. 303.

${ }^{26}$ Cz. Miłosz, Traktat poetycki z moim komentarzem, s. 38.

${ }^{27}$ Tenże, Wiersze, t. 3, Kraków 1993, s. 105.

${ }^{28}$ Tamże, t. 2, s. 75.

${ }^{29}$ T. Skubalanka, Język poezji Czestawa Miłosza, Lublin 2006, s. 9.

${ }^{30} \mathrm{Cz}$. Miłosz, Wiersze, t. 2, s. 162.

31 Tamże, s. 163. 
snego języka, przeszłości i tradycji kulturalnej”32. By jednak owej apologii dokonać, sięga Miłosz po narzędzia oglądu literatury, które umożliwiają mu wskazanie elementów w opisie rzeczywistości, na które — jako poeta — zgodzić się nie może.

Tony polemiczne - z syntetycznym przywołaniem głównych cech poezji jako kontekstu dyskusyjnego - pojawiają się także w wierszu Przeciwko poezji Filipa Larkina. Ten angielski ,poeta «intensywnego smutku»”, jak nazwał Larkina Barańczak ${ }^{33}$, nie pozostawiał złudzeń, co do egzystencjalnej, przygniatającej pustki, jaka jest domeną ludzkiego żywota. W wierszu Dockery i syn (utworze „klasycznie Larkinowskim”,34, włączonym przez Barańczaka do tomu Atlantyda i inne wiersze z lat 1981-1985) pisze:

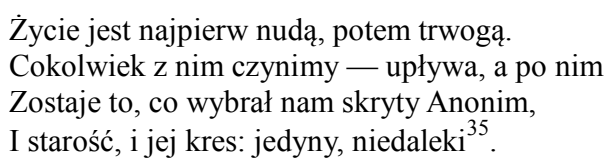

Smutne konstatacje Larkina oceniają kondycję człowieka bardzo nisko - większą część życia człowiek się po prostu nudzi, by następnie zdjęła go przejmująca trwoga. Miłosz w swoim wierszu-polemice zauważa, że angielski poeta ,wierszem wylicza powody rozpaczy". Natychmiast dodaje, że jednak nie ma za co Larkinowi dziękować. Jego poezja jest bowiem przygnębiająca, „straszy śmiercią”, czym „spycha” na „niższe poziomy świadomości”. I w wypadku tego wiersza autor Sroczości odnajduje nadrzędną cechę twórczości omawianego poety. Jej wysłowienie pozwala mu na zajęcie całkowicie odmiennego stanowiska, w którym Miłosz bez wahania stwierdza:

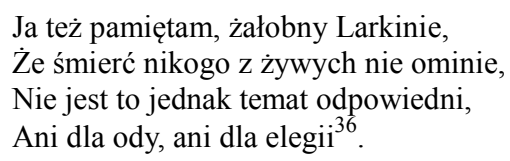

„Krytyka” literacka, jakiej dokonuje Miłosz w swoich wierszach o funkcji polemicznej, dobitnie wskazuje na jego literaturoznawcze kompetencje. Czesław Miłosz, profesor literatury słowiańskiej w Berkeley, bardzo często wykorzystuje swoją literaturoznawczą wiedzę w procesie tworzenia wierszy. Dlatego tak wiele stylizacji, aluzji i polemik w tej twórczości ${ }^{37}$. Stanowi wszakże autor Drugiej przestrzeni przykład poety, który stał się uczonym i w swym dziele zespolił obie te maski, otrzymując w wyniku tego jeden z najwspanialszych modeli — ,poezję literaturoznawczą”, która (pomimo dość „szkolnej” proweniencji) dowodzi po raz kolejny, że literatura jest obiegiem otwartym, a jej składniki przenikają się wzajem. Omówiona tendencja ocala również jedną z głównych powinności poety, tak wyłożoną w wierszu Czeladnik:

Nam poruczono przechowanie daru

I uchronienie go od zgiełku mass mediów ${ }^{38}$.

${ }^{32}$ A. Fiut, Moment wieczny. Poezja Czestawa Miłosza, Kraków 1998, s. 269.

${ }^{33}$ S. Barańczak, Wstep: intensywność smutku, [w:] P. Larkin, 44 wiersze, wybór, przekł., wstęp i oprac. S. Barańczak, Kraków 1991, s. 14.

34 Tamże, s. 5.

${ }^{35}$ P. Larkin, 44 wiersze, s. 85.

${ }^{36}$ Wszystkie cytaty z wiersza Przeciwko poezji Filipa Larkina pochodzą z: Cz. Miłosz, Wiersze, t. 5, Kraków 2009, s. 136.

${ }^{37}$ Szerzej na ten temat pisze A. Fiut w swej monografii o Miłoszu, szczególnie w rozdziale Palimpsest; zob. A. Fiut, Moment wieczny, s. 247-303.

${ }^{38}$ Cz. Miłosz, Wiersze, t. 5, s. 254. 


\section{POETIC HISTORY AND CRITICISM OF LITERATURE IN PERSPECTIVE OF CZESŁAW MIŁOSZ}

The article presents a reflection on those poems by Czesław Miłosz which reflect the trend of meditation on literature. It is about the texts in which the creativity of other poets and literature as such are made the subject of reflection by Miłosz. The Professor of Slavic literature at the University of California reconstructs poetic style, poetry conception and language of various authors, entering their achievements in historic time and historical-literary process (the most important in this respect is A Treatise on Poetry). In Miłosz's poetry, one can find numerous traces of his literary competencies. The poet also uses them in his literary polemics (characteristic poem Against Philip Larkin Poetry), what mentions critic-literary endeavours. In the present article, the works of Miłosz connected with a reflection on literature appear to be a sign of a broader tendency in contemporary poetry — its inclination for metafiction.

KEY WORDS: Polish poetry in the 20th century; Cz. Miłosz; metafiction. 